\title{
Association between Herbivore Resistance and Fruit Quality in Apple
}

\author{
Sibylle Stoeckli ${ }^{1}$, Karsten Mody ${ }^{2}$, and Silvia Dorn \\ ETH Zurich, Institute of Plant Sciences/Applied Entomology, Schmelzbergstrasse \\ 9/LFO, CH-8092 Zurich, Switzerland
}

Markus Kellerhals

Agroscope Changins-Waedenswil Research Station ACW, P.O. Box, Schloss, CH-8820 Waedenswil, Switzerland

Additional index words. Malus $\times$ domestica, marker assisted selection, fruit quality, herbivore resistance, resource allocation tradeoff

\begin{abstract}
Enhanced fruit quality, plant health, and productivity are major objectives in apple breeding. The undesirable fruit quality traits frequently associated with pest- and disease-resistant cultivars may be related to resource allocation tradeoffs. The objective of the present study was to evaluate the association between insect resistance and fruit quality in apple. The studied 'Fiesta' $\times$ 'Discovery' apple progeny was characterized by reasonable fruit firmness and optimal sugar content and acidity but small fruit size. There was a positive correlation between codling moth (Cydia pomonella) fruit infestation and fruit firmness. Additionally, a positive correlation was detected between shoot infestation by green apple aphid (Aphis pomi), fruit number as well as sugar content. Infestation by the apple leaf miner moth (Lyonetia clerkella), the rosy apple aphid (Dysaphis plantaginea), the leaf-curling aphid (Dysaphis cf. devecta), and the apple rust mite (Aculus schlechtendali) was not significantly related to fruit quality traits. The positive relationship of increased infestation by some pest insects and quality-determining fruit characteristics such as firmness or sugar content points to a possibly increased necessity for plant protection measures in apple cultivars producing high-quality fruits. One possible explanation of higher pest infestation in cultivars producing fruits with high quality is a tradeoff between resource allocation to defensive secondary metabolites or to fruit quality. By identifying a relationship between pest infestation and fruit quality, the present study highlights the need to consider pest resistance when breeding for highquality apple cultivars. The use of genetic markers for fruit quality and pest resistance in marker-assisted breeding may facilitate the combined consideration of fruit quality and pest resistance in apple breeding programs.
\end{abstract}

Host-plant resistance is a principal component of the management of pests and diseases in an integrated cropping system (Kellerhals, 2009). In addition to enhanced plant health, crop yield, tree architecture, storability, and consumer preference are the major aspects in apple breeding (Beers et al., 2003; Egger et al., 2009a, 2009b). Desirable fruit traits include flavor, juiciness, sweetness,

Received for publication 11 Aug. 2010. Accepted for publication 29 Sept. 2010.

We thank Cesare Gessler (ETH Zurich), Mauro Jermini, Danilo Christen, and Reto Leumann (Agroscope Changins-Waedenswil Research Station ACW) for access to and maintenance of the study orchards; Michelle Schmocker, Christoph Rohrer, Claudia Good. and Sandra Noser for help with fieldwork; Caroline Baumgartner for help with mite filtration; Lorenz Kreis (Genossenschaft Migros Ostschweiz) for fruit trait determination; Robert Liebhard (Tecan AG) for access to the fruit quality data set; and Adriana Najar-Rodriguez for useful comments to an earlier version of the article. ${ }^{1}$ Present address: Agroscope Changins-Waedenswil Research Station ACW, P.O. Box, Schloss, CH-8820 Waedenswil, Switzerland.

${ }^{2}$ To whom reprint requests should be addressed; e-mail karsten.mody@ipw.agrl.ethz.ch. firmness, acidity, size, and color (Eigenmann and Kellerhals, 2007). Preference is given to fruit that is crisp (firmness $8 \mathrm{~kg} \cdot \mathrm{cm}^{-2}$ ), sweet (sugar content 12 to $13^{\circ} \mathrm{Brix}$ ), and mediumsized (diameter 70 to $80 \mathrm{~mm}$ ) with excellent color and shelf life (Egger et al., 2009b). In apple (Malus $\times$ domestica Borkh.), several quantitative trait loci (QTLs) or major genes for disease (Calenge and Durel, 2006; Khan et al., 2006) and pest resistance (Bus et al., 2008; Roche et al., 1997; Stoeckli et al., 2008b, 2008c, 2009; Wearing et al., 2003) as well as fruit quality traits (Cevik et al., 2010; Costa et al., 2008; Liebhard et al., 2003) have been identified. This highlights the potential usefulness of marker-assisted selection in targeted apple breeding (Baumgartner et al., 2010; Kellerhals, 2009).

The most basic energy resources of green plants are carbohydrates, proteins, and lipids. The allocation of resources to plant growth (e.g., tree growth, fruit yield, and quality) is costly and competes with the production of defensive compounds (e.g., phenolics, terpenoids, or glucosinolates) (Gayler et al., 2004; Koricheva, 2002). This tradeoff between demands for growth and defense is especially relevant in perennial crop plants. These crops are bred and grown for maximized yield
(Kaplan et al., 2009; Koricheva et al., 1998) but often have a limited capacity for effective defense against pests as a result of allocation of resources to persistent plant organs and because of their relatively low intimacy of association with the economically most damaging pests (Coley et al., 1985; Mattson et al., 1988). Expression of plant defenses would, however, be particularly important for perennial crops such as apple orchards. Plants in such perennial systems are confronted with a notable diversity of pests but also with effective natural enemies, which can be supported by adequate pest management schemes incorporating plant defense to reduce pesticide use (Beers et al., 2003; Dorn et al., 1999; Zehnder et al., 2007).

Disease-resistant cultivars often have undesirable fruit traits (Kellerhals et al., 2004b), which underlines a possible resource allocation tradeoff. Evaluation of fruit quality traits is highly relevant because the fruit is the marketable product of an apple tree, and breeding for disease and pest-resistant apple cultivars should always be performed under consideration of marketable fruit quality (Brown and Maloney, 2003). The objective of the present study was to evaluate the association between insect resistance and different fruit quality traits in apple. Enhanced knowledge on resource allocation tradeoffs in apple may be considered in breeding programs aiming at high-quality disease- and pest-resistant apples.

\section{Materials and Methods}

Plant material and study sites. Herbivore resistance and fruit quality were assessed on a 'Fiesta' $\times$ 'Discovery' (Malus $\times$ domestica Borkh.) $F_{1}$ progeny. Progeny genotypes were bud-grafted on M27 rootstocks, and each of 250 genotypes was planted in winter 19981999 at three study sites in Switzerland (Liebhard et al., 2003): Cadenazzo (Ticino; lat. $46^{\circ} 09^{\prime} 35^{\prime \prime} \mathrm{N}$, long. $8^{\circ} 56^{\prime} 00^{\prime \prime} \mathrm{E} ; 203-\mathrm{m}$ altitude), Conthey (Valais; lat. $46^{\circ} 12^{\prime} 30^{\prime \prime} \mathrm{N}$, long. $7^{\circ} 18^{\prime} 15^{\prime \prime} \mathrm{E} ; 478-\mathrm{m}$ altitude), and Waedenswil (Zurich; lat. $47^{\circ} 13^{\prime} 20^{\prime \prime} \mathrm{N}$, long. $8^{\circ} 40^{\prime} 05^{\prime \prime} \mathrm{E}$; 455-m altitude). The distance between trees was $0.5 \mathrm{~m}$ in Conthey and Waedenswil and $1.5 \mathrm{~m}$ in Cadenazzo. Trees were planted in rows $3.5 \mathrm{~m}$ apart from each other. Climate conditions at the three sites were characterized by highest temperature in Cadenazzo (mean annual temperature: $10.5^{\circ} \mathrm{C}$, total annual rainfall: $1772 \mathrm{~mm}$; 30 year average; MeteoSwiss) and lowest amount of rainfall in Conthey $\left(9.2{ }^{\circ} \mathrm{C}, 598\right.$ $\mathrm{mm})$ compared with Waedenswil $\left(8.7^{\circ} \mathrm{C}\right.$, $1353 \mathrm{~mm}$ ). Orchards were treated with fertilizers and herbicides, but no insecticides and fungicides were applied. Fruit thinning was carried out by hand. In 2009, insecticide and fungicide treatments were carried out to achieve acceptable fruit quality.

Herbivore resistance. Herbivore infestation per tree was used as a measure of resistance to two lepidopteran, three aphid, and one mite species. Herbivore assessment was carried out on 160 apple genotypes in 
study Years 1 and 2 (2005 and 2006). The number of codling moth (Cydia pomonella L.) larval penetrations in fruits was inspected only on fruits attached to the tree, not on fallen fruits (Stoeckli et al., 2009). All leaf mines of the apple leaf miner (Lyonetia clerkella L.) were counted for each individual tree by examining every leaf at the end of July in 2005. At this time of the year, mines from all generations (two to three per year) should be visible and the quantified infestation level should therefore be representative for the whole year (Baggiolini et al., 1992). The rosy apple aphid (Dysaphis plantaginea Pass.) was assessed by evaluation of the number of colonies (Stoeckli et al., 2008b). The number of red-curled leaves was taken as a measure of leaf-curling aphid (Dysaphis cf. devecta Wlk.) infestation (Stoeckli et al., 2008b). The number of individual aphids was counted to quantify overall resistance to the green apple aphid (Aphis pomi De Geer) (Stoeckli et al., 2008b). To evaluate rust mite (Aculus schlechtendali Nalepa) resistance in apple, mites were extracted from 24 leaves per tree in $200 \mathrm{~mL}$ of a $0.1 \%$ Etalfix solution (surface-active agent; gvz-rossat, Otelfingen, Switzerland) (Stoeckli et al., 2008c). Several surveys per year were carried out for evaluation at the three study sites in 2005 and 2006. Herbivore surveys were based on one (L. clerkella and A. schlechtendali) to four (A. pomi) assessments per season. Because $C$. pomonella was controlled by mating disruption at Waedenswil, this site was not considered for evaluation of resistance to this species. For each herbivore and survey, the total infestation (e.g., number of C. pomonella larval penetrations on the studied progeny plants) was calculated, and the relative infestation (RI) in percentage of this total was determined for each progeny plant. RI from several surveys was averaged for statistical analysis.

Fruit traits. Fruit number was assessed in study Years 1 and 2 simultaneously with the herbivore survey. Weight, firmness, sugar content, and acidity of fruits produced by the study trees were measured on 100 progeny trees at the Waedenswil site in study Year 3 (2009). Trees were inspected for fruit maturity two times per week from 20 July to 7 Sept., and fruits were collected for further processing on the genotype-specific harvest date (BBCH Stage 87; Meier, 2001), when they had reached optimal fruit quality for picking. Fruits with no herbivore damage were selected. An automated fruit analyzer, Pimprenelle (Setop Giraud Technology, 84300 Cavaillon, France), was used to assess fruit quality traits. Fruit firmness $\left(\mathrm{kg} \cdot \mathrm{cm}^{-2}\right)$ of skinned cortex tissue was determined with a $11-\mathrm{mm}$ probe, a penetration speed of 4.0 $\mathrm{mm} \cdot \mathrm{s}^{-1}$, and penetration depth of $8.0 \mathrm{~mm}$. Sugar was assessed in ${ }^{\circ}$ Brix, which equals grams of sugar per $100 \mathrm{~mL}$ juice. Fruit acidity was determined as grams malic acid per liter juice. Fruit traits of the same progeny plants had also been assessed in 2000 (Liebhard et al., 2003). These data served for an acrossyear comparison.
Statistical analysis. Spearman's rank correlation test was used to analyze the association between herbivore resistance and fruit quality, and the Benjamini-Hochberg correction for Type I errors in multiple tests was applied (Verhoeven et al., 2005). All statistics were carried out with R 2.7.0 for Mac OS X (http://www.stat.ethz.ch/CRAN/).

\section{Results}

Herbivore abundance. Mean RI of the progeny plants (average from several surveys covering two to three study sites and 2 consecutive years) was $0.7 \pm 0.1$ (all study species) and ranged between completely uninfested trees $(\mathrm{RI}=0 \%$; all herbivores species) and $10.6 \%$ (D. plantaginea), $8.7 \%$ (C. pomonella), 8.6\% (D. cf. devecta), 7.4\% (A. pomi), 6.4\% (A. schlechtendali), and $4.1 \%$ (L. clerkella) infestation. The number of completely uninfested genotypes was 57 (D. cf. devecta), 17 (C. pomonella), six ( $A$. schlechtendali), four (D. plantaginea), two (L. clerkella), and one (A. pomi). Maximum RI values of the progeny trees for a specific survey were in the range of $60 \%$ to $70 \%(D$. plantaginea, A. pomi; Cadenazzo).

Fruit traits. Mean harvest date for the 'Fiesta' $\times$ 'Discovery' progeny genotypes was $16 \pm 1$ Aug. (mean $\pm \mathrm{SE}$ ) and varied between 4 Aug. and 24 Sept. $(\mathrm{CV} \%=4.8)$. Fruit color was a variable red-orange flush with a light green-yellow background. Fruits were small in size (mean \pm SE: $120 \pm 3 \mathrm{~g}$ ) but firm and crisp $\left(9.2 \pm 0.2 \mathrm{~kg} \cdot \mathrm{cm}^{-2}\right)$. Sugar content was determined to amount to $10.8 \pm$ $0.1^{\circ}$ Brix, and acidity was characterized by $9.5 \pm 0.4 \mathrm{~g} \cdot \mathrm{L}^{-1}$ malic acid (Table 1 ). The $\mathrm{CV} \%$ ranged between $8 \%$ (sugar content) and $62 \%$ (fruit number; Table 1). Fruit weighed between $101 \mathrm{~g}$ and $138 \mathrm{~g}$, and fruit firmness ranged between $8.0 \mathrm{~kg} \cdot \mathrm{cm}^{-2}$ and 10.0 $\mathrm{kg} \cdot \mathrm{cm}^{-2}$, respectively, and these values were determined for $50 \%$ of the randomly chosen fruits. The corresponding percentiles for sugar content were 10 and $11^{\circ}$ Brix and for acidity $7 \mathrm{~g} \cdot \mathrm{L}^{-1}$ and $12 \mathrm{~g} \cdot \mathrm{L}^{-1}$ malic acid, respectively. Mean fruit number, fruit weight, fruit firmness, sugar content, and acidity were not significantly correlated with each other ( $P>0.05$; Spearman's rank test).

Fruit trait comparison between sites and across years. Fruit firmness was significantly correlated between the site Waedenswil (study Year 3) and the two other study sites (Year 2000; Cadenazzo: $\mathrm{n}=33, r_{\mathrm{s}}=0.588$, $P<0.001$; Conthey: $\mathrm{n}=22, r_{\mathrm{s}}=0.512, P=$ 0.015; Spearman's rank test). Apple fruit in Cadenazzo and Conthey were comparable considering sugar content $\left(\mathrm{n}=93, r_{\mathrm{s}}=\right.$ $0.522, P<0.001$; Spearman's rank test), but there was no significant relationship between the sugar content at these two sites and the sugar content at Waedenswil $(P>0.05)$. Fruit firmness, sugar content, and acidity at the Waedenswil site were comparable between Years 2000 (Liebhard et al., 2003) and 2009 (i.e., study Year 3; Table 1). There was a significant across-year correlation for acidity $\left(\mathrm{n}=20, r_{\mathrm{s}}=0.641, P=0.002\right.$; Spearman's rank test) and for firmness ( $\mathrm{n}=19, r_{\mathrm{s}}=0.601$, $P=0.007$; Spearman's rank test), but not for sugar content $\left(\mathrm{n}=20, r_{\mathrm{s}}=0.254, P=0.280\right.$; Spearman's rank test). Mean fruit weight was not significantly correlated between Year 2000 and study Year $3\left(\mathrm{n}=20, r_{\mathrm{s}}=0.412\right.$, $P=0.080$; Spearman's rank test; Table 1). Although mean fruit number was higher in 2005 and 2006 (i.e., study Years 1 and 2) than in Year 2000 as a result of tree age (Table 1), a significant across-year correlation in fruit number was identified $\left(\mathrm{n}=33, r_{\mathrm{s}}=0.481, P=\right.$ 0.005; Spearman's rank test).

Association between herbivore resistance and fruit quality. A significant positive correlation between $C$. pomonella infestation and fruit firmness was found $\left(\mathrm{n}=64, r_{\mathrm{s}}=0.297\right.$,

Table 1. Fruit traits of 'Fiesta' $\times$ 'Discovery' progeny genotypes in study Years 1 and 2 (2005 and 2006; fruit number) and study Year 3 (2009; fruit weight, fruit firmness, sugar content, acidity) at one study site (Waedenswil).

\begin{tabular}{|c|c|c|c|c|c|}
\hline Fruit trait & No. & Mean \pm SE & $\mathrm{cv}(\%)^{\mathrm{y}}$ & Minimum & Maximum \\
\hline \multicolumn{6}{|l|}{ Fruit number } \\
\hline Study Years 1 and 2 & 157 & $35.0 \pm 1.7$ & 61 & 4.0 & 119.0 \\
\hline Liebhard et al. (2003) & 54 & $6.5 \pm 0.8$ & 90 & 1.0 & 30.0 \\
\hline \multicolumn{6}{|l|}{ Fruit weight (g) } \\
\hline Study Year 3 & 85 & $120.0 \pm 3.1$ & 24 & 64.0 & 184.0 \\
\hline Liebhard et al. (2003) & 54 & $99.0 \pm 4.9$ & 36 & 33.0 & 199.0 \\
\hline \multicolumn{6}{|l|}{ Fruit firmness $\left(\mathrm{kg} \cdot \mathrm{cm}^{-2}\right)$} \\
\hline Study Year 3 & 85 & $9.2 \pm 0.2$ & 19 & 4.0 & 14.0 \\
\hline Liebhard et al. (2003) & 54 & $10.9 \pm 0.3$ & 23 & 5.2 & 17.9 \\
\hline \multicolumn{6}{|l|}{ Sugar content $\left({ }^{\circ} \text { Brix }\right)^{\mathrm{x}}$} \\
\hline Study Year 3 & 99 & $10.8 \pm 0.1$ & 8 & 9.0 & 13.0 \\
\hline Liebhard et al. (2003) & 54 & $12.3 \pm 0.2$ & 9 & 9.5 & 16.4 \\
\hline \multicolumn{6}{|l|}{ Acidity $\left(\mathrm{g} \cdot \mathrm{L}^{-1}\right.$ malic acid $)$} \\
\hline Study Year 3 & 97 & $9.5 \pm 0.4$ & 38 & 3.0 & 19.0 \\
\hline Liebhard et al. (2003) & 54 & $8.9 \pm 0.5$ & 41 & 3.3 & 18.7 \\
\hline
\end{tabular}

${ }^{\mathrm{z} F r u i t}$ traits of the same progeny plants had been assessed in 2000 (Liebhard et al., 2003) and are presented here for comparison.

${ }^{\mathrm{y}} \mathrm{CV} \%=(\mathrm{sD} /$ mean $) \times 100$.

${ }^{\mathrm{x}}$ Sugar $(\mathrm{g})$ per $100 \mathrm{~mL}$ juice at $20^{\circ} \mathrm{C}$. 
Table 2. Association between herbivore resistance and fruit quality traits (Spearman's rank correlation test). ${ }^{\mathrm{z}}$

\begin{tabular}{|c|c|c|c|c|c|c|c|}
\hline & No. & Cydia pomonella & Lyonetia clerkella & Dysaphis plantaginea & Dysaphis cf. devecta & Aphis pomi & Aculus schlechtendal \\
\hline Fruit number & 155 & 0.06 & 0.040 & -0.010 & -0.017 & $0.269^{* *}$ & -0.030 \\
\hline Fruit weight & 64 & 0.141 & -0.052 & -0.068 & 0.115 & 0.156 & $0.256^{*}$ \\
\hline Fruit firmness & 64 & $0.297^{*}$ & 0.069 & -0.138 & -0.232 & -0.090 & -0.119 \\
\hline Sugar content & 75 & -0.098 & 0.161 & 0.052 & 0.058 & $0.337 * *$ & 0.199 \\
\hline Acidity & 72 & -0.040 & -0.133 & 0.008 & -0.129 & -0.157 & -0.096 \\
\hline
\end{tabular}

${ }^{\mathrm{z}}$ Correlations are based on mean herbivore relative infestation rate (RI, \%) ${ }^{\mathrm{y}}$ in study Years 1 and 2 (2005 and 2006$)$ at three study sites, mean fruit number (Years 1 and 2), and mean fruit weight (g), fruit firmness $\left(\mathrm{kg} \cdot \mathrm{cm}^{-2}\right)$, sugar content $\left({ }^{\circ}\right.$ Brix), and acidity $\left(\mathrm{g} \cdot \mathrm{L}^{-1} \mathrm{malic}\right.$ acid) in Year $3(2009)$ at one study site $(\mathrm{Waedenswil)}$. Significant correlations after control of false discovery rate (multiple comparisons) are indicated: $* P<0.05, * * P<0.01$.

${ }^{\mathrm{y}}$ Relative infestation (RI) is the percentage of the total infestation for each progeny plant and survey. RI from several surveys considering three study sites and 2 consecutive years was averaged for statistical analysis.

$P=0.017$; Spearman's rank test, Table 2). For $A$. pomi, a significant positive relationship between aphid number and fruit number (n $\left.=155, r_{\mathrm{s}}=0.269, P=0.001\right)$ as well as aphid number and sugar content $\left(\mathrm{n}=74, r_{\mathrm{s}}=\right.$ $0.337, P=0.003$ ) was detected. The same relationship was found considering $A$. pomi abundance at the Waedenswil site alone, which underlines the generality of the identified effects (fruit number: $\mathrm{n}=152, r_{\mathrm{s}}=0.218$, $P=0.007$; sugar content: $\mathrm{n}=74, r_{\mathrm{s}}=0.469, P$ $=0.0001)$. There was no significant correlation between apple infestation with $L$. clerkella, D. plantaginea, $D$. cf. devecta, or $A$. schlechtendali and any quantified fruit quality trait $(P>0.05$, Spearman's rank test; Table 2$)$.

\section{Discussion}

The present study used 250 'Fiesta' $\times$ 'Discovery' progeny plants to relate fruit traits to infestation by major apple pests. A strong variation in fruit traits among apple genotypes was observed ( $\mathrm{CV}$ up to 61\%), providing a sound basis to study the association between herbivore resistance and fruit traits. Although variable, the average firmness, sugar content, and acidity of the studied genotypes were comparable to commercial cultivars such as Ariane, Iduna, and Braeburn (Egger et al., 2009b; Kellerhals et al., 2004a). Infestation by codling moth, Cydia pomonella, and green apple aphid, Aphis pomi, was correlated to some quality-determining fruit traits, whereas infestation by other major apple herbivores was not related to the studied fruit traits.

C. pomonella infestation was positively correlated to fruit firmness. Fruit firmness declines during fruit maturation (Volz et al., 2003), and phenolic compounds or volatile emissions attracting or repelling $C$. pomonella undergo qualitative and quantitative changes during fruit ripening (Hern and Dorn, 2003, 2004; Mayr et al., 1995; Vallat and Dorn 2005). Therefore, fruit maturity may be a factor determining apple infestation by $C$. pomonella in addition to other leaf or fruit traits such as high trichome density (Plourde et al., 1985), wax deposits (Hagley et al., 1980), or lignification (Westigard et al., 1975). So far, the effects of the latter traits on $C$. pomonella infestation have been studied only for a limited number of cultivars or selections, but they should be effectively testable in segregating progenies comprising a marked variation of the respective trait. First-generation $C$. pomonella larvae prefer larger fruit to smaller fruit (Stoeckli et al., 2008a). Such larger fruit may be riper and less firm at this stage and may allocate more resources in fruit growth compared with defensive compounds. Later on, C. pomonella larvae may prefer unripe and firm fruits for secured larval development before fruit fall. For $A$. pomi, we found a positive correlation between pest infestation and fruit number or sugar content. Producing fruits of high firmness and sugar content has a high metabolic cost (e.g., $1.15 \mathrm{~g}$ glucose/g dry weight for fruit production) (Walton et al., 1999), and it may compete with production of secondary defense compounds (Gayler et al., 2004; Ruhmann et al., 2002). The positive correlation between $A$. pomi infestation and fruit number or sugar content may also reflect aspects of tree vigor with more vigorously growing genotypes producing more fruits or fruits of higher sugar content and providing at the same time best conditions for $A$. pomi population development (Stoeckli et al., 2008d). The relationship among tree vigor, fruit sugar content, and resistance to aphids may be explored in more depth also for commercial cultivars that are known to be variably resistant to aphids (see Stoeckli et al., 2008b, for an overview of resistant apple cultivars).

No significant association between Lyonetia clerkella, Dysaphis plantaginea, D. cf. devecta, or Aculus schlechtendali infestation and fruit traits was found. The tradeoff between growth and phenotypic expression of defensive traits to these species may be weak in the studied agricultural environment with suitable nutrient and light conditions. The detection of a possible tradeoff may also be impeded by weak phenotypic correlations (Koricheva, 2002), and it may be masked by long-term losses in perennial plants (e.g., growth distortion caused by aphids affecting productivity of subsequent years; Welling et al., 1989) or a relatively low genetic basis of resistance in the studied apple progeny to most herbivores (Stoeckli et al., 2008c). Complex interactions affecting resource allocation may also hamper identification of tradeoffs. This is illustrated by the varying effects of nitrogen-fertilization on scab susceptibility of apple cultivars susceptible and resistant to apple scab. Whereas scab susceptibility of 'Golden Delicious' was increased by fertilization, it was unaffected in 'Rewena' despite a reduction in phenolic compounds (Leser and Treutter, 2005). However, 'Rewena' carries the $\mathrm{V}_{f}$ resistance gene originating from Malus floribunda 821, so no scab should be found on this cultivar.

The finding that the association between herbivore resistance and fruit quality was not strongly expressed highlights the potential to breed high-quality pest-resistant apple cultivars by marker-assisted selection, similar to fire blight-resistant high-quality apples (Baumgartner et al., 2010; Kellerhals, 2009). A genetic basis of herbivore resistance (Stoeckli et al., 2008b, 2008c, 2009) and of fruit traits (Liebhard et al., 2003) in the 'Fiesta' $\times$ 'Discovery' progeny was indicated by detection of QTLs and emphasized by the across-year stability of the studied fruit traits. Studies in other genetic backgrounds or under different environmental conditions may complement our findings and help to assess whether resource allocation tradeoffs between plant growth traits and insect resistance are in general and in the context of climate change no obstacle for successful apple breeding.

\section{Literature Cited}

Baggiolini, M., E. Keller, H.G. Milaire, and H. Steiner. 1992. Visuelle Kontrollen im Apfelanbau. Schweizerische Zentrale für Obstbau, Oeschberg, Koppigen, $\mathrm{CH}$.

Baumgartner, I., L. Frank, G. Silvestri, A. Patocchi, B. Duffy, J. Frey, and M. Kellerhals. 2010. Advanced strategies for breeding fire blight resistant high quality apples. 14th Int. Conf. Organ. Fruit-Growing 414:31-37.

Beers, E.H., D.M. Suckling, R.J. Prokopy, and J. Avilla. 2003. Ecology and management of apple arthropod pests, p. 489-514. In: Ferree, D.C. and I.J. Warrington (eds.). Apples: Botany, production and uses. CABI Publishing, Wallingford, UK.

Brown, S.K. and K.E. Maloney. 2003. Genetic improvement of apple: Breeding, markers, mapping and biotechnology, p. 31-61. In: Ferree, D.C. and I.J. Warrington (eds.). Apples: Botany, production and uses. CABI Publishing, Wallingford, UK.

Bus, V.G.M., D. Chagné, H.C.M. Bassett, D. Bowatte, F. Calenge, J.-M. Celton, C.-E. Durel, M.T. Malone, A. Patocchi, A.C. Ranatunga, E.H.A. Rikkerink, D.S. Tustin, J. Zhou, and S.E. Gardiner. 2008. Genome mapping of three major resistance genes to woolly apple aphid (Eriosoma lanigerum Hausm.). Tree Genet. Genomes 4:223-236.

Calenge, F. and C.-E. Durel. 2006. Both stable and unstable QTLs for resistance to powdery mildew are detected in apple after four years of field assessment. Mol. Breed. 17:329-339.

Cevik, V., C.D. Ryder, A. Popovich, K. Manning, G.J. King, and G.B. Seymour. 2010. A fruitfullike gene is associated with genetic variation for fruit flesh firmness in apple (Malus 
domestica Borkh.). Tree Genet. Genomes 6:271-279.

Coley, P.D., J.P. Bryant, and F.S. Chapin. 1985. Resource availability and plant antiherbivore defense. Science 230:895-899.

Costa, F., W.E. van de Weg, S. Stella, L. Dondini, D. Pratesi, S. Musacchi, and S. Sansavini. 2008. Map position and functional allelic diversity of $M d-\operatorname{Exp} 7$, a new putative expansin gene associated with fruit softening in apple (Malus $\times$ domestica Borkh.) and pear (Pyrus communis). Tree Genet. Genomes 4:575-586.

Dorn, S., P. Schumacher, C. Abivardi, and R. Meyhofer. 1999. Global and regional pest insects and their antagonists in orchards: Spatial dynamics. Agr. Ecosyst. Environ. 73:111-118.

Egger, S., S. Capaul, and M. Kellerhals. 2009a. Vergleich neuer Apfelsorten: Ertrag und Baumeigenschaften. Schweiz. Z. Obst- und Weinbau 12:8-11.

Egger, S., S. Capaul, and M. Kellerhals. 2009b. Vergleich neuer Apfelsorten: Fruchtqualität. Schweiz. Z. Obst- und Weinbau 13:8-11.

Eigenmann, C. and M. Kellerhals. 2007. Welche Äpfel wollen die Konsumentinnen und Konsumenten? Agrarforschung 14:6-9.

Gayler, S., C. Leser, E. Priesack, and D. Treutter. 2004. Modelling the effect of environmental factors on the "trade-off" between growth and defensive compounds in young apple trees. Trees-Struct. Funct. 18:363-371.

Hagley, E.A.C., J.F. Bronskill, and E.J. Ford. 1980. Effect of the physical nature of leaf and fruit surfaces on ovipositon by the codling moth (Cydia pomonella) (Lepidoptera: Tortricidae). Can. Entomol. 112:503-510.

Hern, A. and S. Dorn. 2003. Monitoring seasonal variation in apple fruit volatile emission in situ using solid-phase microextraction. Phytochem. Anal. 14:232-240.

Hern, A. and S. Dorn. 2004. A female-specific attractant for the codling moth (Cydia pomonella) from apple fruit volatiles. Naturwissenschaften 91:77-80.

Kaplan, I., G.P. Dively, and R.F. Denno. 2009. The costs of anti-herbivore defense traits in agricultural crop plants: A case study involving leafhoppers and trichomes. Ecol. Appl. 19: 864-872.

Kellerhals, M. 2009. Introduction to apple (Malus $\times$ domestica), p. 73-84. In: Folta, K.M. and S.E. Gardiner (eds.). Genetics and genomics of Rosaceae. Springer, New York, NY.

Kellerhals, M., S. Gantner, and C. Krebs. 2004a. Neue Apfelsorten auf dem Prüfstand. Schweiz. Z. Obst- und Weinbau 12:8-11.

Kellerhals, M., C. Sauer, B. Guggenbuehl, S. Gantner, B. Frey, J.E. Frey, A. Patocchi, and C. Gessler. 2004b. Apple breeding for high fruit quality and durable disease resistance. Acta Hort. 663:751-756.

Khan, M.A., B. Duffy, C. Gessler, and A. Patocchi. 2006. QTL mapping of fire blight resistance in apple. Mol. Breed. 17:299-306.

Koricheva, J. 2002. Meta-analysis of sources of variation in fitness costs of plant antiherbivore defenses. Ecology 83:176-190.

Koricheva, J., S. Larsson, E. Haukioja, and M. Keinanen. 1998. Regulation of woody plant secondary metabolism by resource availability: Hypothesis testing by means of meta-analysis. Oikos 83:212-226.

Leser, C. and D. Treutter. 2005. Effects of nitrogen supply on growth, contents of phenolic compounds and pathogen (scab) resistance of apple trees. Physiol. Plant. 123:49-56.

Liebhard, R., M. Kellerhals, W. Pfammatter, M. Jermini, and C. Gessler. 2003. Mapping quantitative physiological traits in apple (Malus $\times$ domestica Borkh.). Plant Mol. Biol. 52:511526.

Mattson, W.J., R.K. Lawrence, R.A. Haack, D.A Herms, and P.-J. Charles. 1988. Defensive strategies of woody plants against different insect-feeding guilds in relation to plant ecological strategies and intimacy of association with insects, p. 3-38. In: Mattson, W.J., J. Levieux, and C. Bernard-Dagan (eds.). Mechanisms of woody plant defenses against insects. Springer, New York, NY.

Mayr, U., D. Treutter, C. Santos-Buelga, H. Bauer, and W. Feucht. 1995. Developmental changes in the phenol concentrations of 'Golden Delicious' apple fruits and leaves. Phytochemistry 38:1151-1155.

Meier, U. 2001. Growth stages of mono- and dicotyledonous plants: BBCH monograph. Federal Biological Research Centre for Agriculture and Forestry, Braunschweig. Blackwell Wissenschaftsverlag, Berlin, Germany.

Plourde, D.F., H.F. Goonewardene, and W.F. Kwolek. 1985. Pubescence as a factor in codling moth, oviposition, and fruit entry in five apple selections. HortScience 20:82-84.

Roche, P., G. van Arkel, and A.W. van Heusden. 1997. A specific PCR assay for resistance to biotypes 1 and 2 of the rosy leaf curling aphid in apple based on an RFLP marker closely linked to the $S d 1$ gene. Plant Breed. 116:567-572.

Ruhmann, S., C. Leser, M. Bannert, and D. Treutter. 2002. Relationship between growth, secondary metabolism, and resistance of apple. Plant Biol. 4:137-143.

Stoeckli, S., K. Mody, and S. Dorn. 2008a. Influence of canopy aspect and height on codling moth (Lepidoptera: Tortricidae) larval infes- tation in apple, and relationship between infestation and fruit size. J. Econ. Entomol. 101:81-89.

Stoeckli, S., K. Mody, C. Gessler, A. Patocchi, M. Jermini, and S. Dorn. 2008b. QTL analysis for aphid resistance and growth traits in apple. Tree Genet. Genomes 4:833-847.

Stoeckli, S., K. Mody, A. Patocchi, M. Kellerhals, and S. Dorn. 2008c. Rust mite resistance in apple assessed by quantitative trait loci analysis. Tree Genet. Genomes 5:257-267.

Stoeckli, S., K. Mody, and S. Dorn. 2008d. Aphis pomi (Hemiptera: Aphididae) population development, shoot characteristics, and antibiosis resistance in different apple genotypes. J. Econ. Entomol. 101:1341-1348.

Stoeckli, S., K. Mody, C. Gessler, D. Christen, and S. Dorn. 2009. QTL mapping of resistance in apple to Cydia pomonella and Lyonetia clerkella, and of two selected fruit traits. Ann. Appl. Biol. 154:377-387.

Vallat, A. and S. Dorn. 2005. Changes in volatile emission from apple trees and associated response of adult female codling moths over the fruit-growing season. J. Agr. Food Chem. 53: 4083-4090.

Verhoeven, K.J.F., L. Simonsen, and L.M. McIntyre. 2005. Implementing false discovery rate control: Increasing your power. Oikos 108:643647.

Volz, R.K., F.R. Harker, and S. Lang. 2003. Firmness decline of 'Gala' apple during fruit development. J. Amer. Soc. Hort. Sci. 128: 797-802.

Walton, E.F., J.N. Wunsche, and J.W. Palmer. 1999. Estimation of the bioenergetic costs of fruit and other organ synthesis in apple. Physiol. Plant. 106:129-134.

Wearing, C.H., K. Colhoun, B. Attfield, R.R. Marshall, and G.F. McLaren. 2003. Screening for resistance in apple cultivars to lightbrown apple moth (Epiphyas postvittana), and greenheaded leafroller (Planotortrix octo) and its relationship to field damage. Entomol. Exp. Appl. 109:39-53.

Welling, P.W., S.A. Wards, A.F.G. Dixon, and R. Rabbine. 1989. Crop loss assessment, p. 49-64. In: Minks, A.K. and P. Harrewijn (eds.). World crop pests. Aphids 2C. Elsevier, Amsterdam, The Netherlands; New York, NY.

Westigard, P.H., L. Gentner, and B.A. Butt. 1975. Codling moth: Egg and first instar mortality of pear with special reference to varietal susceptibility. Environ. Entomol. 5:51-54.

Zehnder, G., G.M. Gurr, S. Kuhne, M.R. Wade, S.D. Wratten, and E. Wyss. 2007. Arthropod pest management in organic crops. Annu. Rev. Entomol. 52:57-80. 